\title{
Feasibility Analysis on the Construction of a Web Solution for Hydrometeorological Forecasting Considering Water Body Management and Indicators for the Pandemic of SARS-COV-2
}

Jose Roberto Dantas da Silva Junior ( $\square$ roberto.dantas@outlook.com )

SENAI CIMATEC Technology College: Faculdade de Tecnologia SENAI CIMATEC https://orcid.org/0000-0002-1854-2743

Rizzieri Pedruzzi

SENAI CIMATEC Technology College: Faculdade de Tecnologia SENAI CIMATEC Filipe Milani de Souza

SENAI CIMATEC Technology College: Faculdade de Tecnologia SENAI CIMATEC Patrick Silva Ferraz

SENAI CIMATEC Technology College: Faculdade de Tecnologia SENAI CIMATEC

Daniel Guimarães Silva

SENAI CIMATEC Technology College: Faculdade de Tecnologia SENAI CIMATEC

Carolina Sacramento Vieira

SENAI CIMATEC Technology College: Faculdade de Tecnologia SENAI CIMATEC

\section{Marcelo Romero de Moraes}

Universidade Federal do Pampa - Campus Bagé: Universidade Federal do Pampa - Campus Bage

\section{Erick Giovani Sperandio Nascimento}

SENAI CIMATEC Technology College: Faculdade de Tecnologia SENAI CIMATEC

Davidson Martins Moreira

SENAI CIMATEC Technology College: Faculdade de Tecnologia SENAI CIMATEC

Research article

Keywords: Water resources, Hydrometeorological forecast, WRF-Hydro, Artificial Intelligence, Sars-CoV-2 (Covid19), MATOPIBA

Posted Date: April 5th, 2021

DOl: https://doi.org/10.21203/rs.3.rs-359251/v1

License: (c) (1) This work is licensed under a Creative Commons Attribution 4.0 International License. Read Full License 



\section{FEASIBILITY ANALYSIS ON THE CONSTRUCTION OF A WEB SOLUTION FOR HYDROMETEOROLOGICAL FORECASTING CONSIDERING WATER BODY MANAGEMENT AND INDICATORS FOR THE PANDEMIC OF SARS-COV-2}

\footnotetext{
1JÚNIOR, José Roberto Dantas da Silva. roberto.dantas@outlook.com. https://orcid.org/0000-00021854-2743.

1PEDRUZZI, Rizzieri. rizzieri.pedruzzi@gmail.com. https://orcid.org/0000-0003-0852-0396.

1SOUZA, Filipe Milani de. filipemilani@outlook.com. https://orcid.org/0000-0003-0295-7474.

1FERRAZ, Patrick Silva. patrick.ferraz@outlook.com. https://orcid.org/0000-0001-9556-3268.

1SILVA, Daniel Guimarães. guimaraessilvadaniel@gmail.com. https://orcid.org/0000-0001-9830-2127. 1VIEIRA, Carolina Sacramento. carolinavieira265@gmail.com. https://orcid.org/0000-0001-5565-1044. 2MORAES, Marcelo Romero de. marcelopato@gmail.com. https://orcid.org/0000-0003-4685-4709. ${ }^{1}$ NASCIMENTO, Erick Giovani Sperandio. erick.sperandio@fieb.org.br. https://orcid.org/0000-00032219-0290.

${ }^{1}$ MOREIRA, Davidson Martins. davidson.moreira@fieb.org.br.https://orcid.org/0000-0002-0902-5218.
} 


\title{
FEASIBILITY ANALYSIS ON THE CONSTRUCTION OF A WEB SOLUTION FOR HYDROMETEOROLOGICAL FORECASTING CONSIDERING WATER BODY MANAGEMENT AND INDICATORS FOR THE PANDEMIC OF SARS-COV-2
}

\author{
JÚNIOR, José Roberto Dantas da Silva \\ PEDRUZZI, Rizzieri \\ SOUZA, Filipe Milani de \\ FERRAZ, Patrick Silva \\ SILVA, Daniel Guimarães \\ VIEIRA, Carolina Sacramento \\ MORAES, Marcelo Romero de \\ NASCIMENTO, Erick Giovani Sperandio \\ MOREIRA, Davidson Martins
}

\begin{abstract}
Currently, the NCAR (U.S. National Center for Atmospheric Research), the institution responsible for the WRF-Hydro (Weather Research and Forecasting Hydro) model initiative, highlights four major global challenges: floods, pollution, droughts, and biodiversity. Thus, given the current scenario of a global pandemic caused by the Sars-CoV-2 virus (Covid19), the importance of hydrological studies, their correlation with contamination levels, and incidence of COVID-19 cases are also in the spotlight. Among the challenges around water resources management, the lack of good and representative data, especially for small water bodies and developing countries, to perform inferences and to manage these natural resources is critical. This situation applies not only to observational data and but also to input data for hydrological models. In this context, the WRF-Hydro system represents the state of the art for hydrometeorological modeling. Thus, the model emerges as a computational tool that becomes possible to provide auxiliary data for patterns analysis in time series and computational prediction. Also, with the evolution of artificial intelligence (Al), it is possible to consider the integration of this modern approach with the WRF-Hydro model simulations. Therefore, the main of this study is to analyze the feasibility of a web tool that integrates these functionalities. The coupled WRF-Hydro with Al will support the management and generate a water predictability analysis in the MATOPIBA region (Maranhão-Tocantins-Piauí-Bahia), northeastern Brazil, the focus area of this study. Although the WRF-Hydro system demonstrates efficiency in the hydrometeorological simulation for the region, the model has a range of subprocesses which has a high computational cost, especially for long-term studies. Therefore, due to the possibility of integrating these computational tools, it is proposed to develop and analyze the construction of a web tool using the WRF-Hydro system for the short and medium-term with Al tools for the short term (a few hours to a few days), to optimize the computational cost. Thus, the combined application of the WRF-Hydro and Al system can improve the water bodies management and assist the identification of contamination levels by Sars-CoV-2, given the presence of the virus in water bodies and the correlation of the pandemic with hydrological variables.
\end{abstract}

Keywords: Water resources, Hydrometeorological forecast, WRF-Hydro, Artificial Intelligence, Sars-CoV-2 (Covid19), MATOPIBA. 


\section{Introduction}

The management of water resources is still a global challenge. The latest United Nations Water Development Report [1] highlights that only $10 \%$ of developing countries have monitoring systems related to water quality. Thus, the advance in the management of water bodies helps in the performance of the system, consisting of a valuable tool for the economy and society. In this sense, the current scenario of a global pandemic caused by the Sars-CoV-2 virus (Covid19) highlights the importance of water studies in sewage systems, which, in turn, are related to major challenges, such as basic sanitation.

The study of [2] indicated that municipalities with poor sanitation are the same with the highest numbers of infections and deaths caused by the Sars-CoV-2 infection. Notoriously, this social problem is related to the management of water resources. Thus, to face these challenges, computational modeling emerges as a precious mechanism for decision-making. However, the hydrometeorological representation requires a model capable of characterizing the hydrology of the Earth's surface-atmosphere, where the availability and measurements of the data are fundamental for understanding the dynamics of a watershed [3].

In this context, the hydrological modeling module of the WRF model, called the WRFHydro system, represents the state of the art regarding water resources, which provides a coupling between an atmospheric model and a hydrological model. The WRF-Hydro system was developed by NCAR in partnership with NASA to model and simulate rainfall, reservoir management, and flood forecasting that allow users to create, save and compare future scenarios. More details when the numerical and computational structure of the model can be obtained [3]. Thus, the WRF-Hydro model has been applied worldwide in studies with flood forecasting and simulation, severe events of precipitation caused by hurricanes, flow simulations in water bodies, soil moisture, evapotranspiration precipitation, and further studies of hydrometeorological conditions, both in arid regions and in humid regions [4-11]. For Brazil, we can mention the work of [12] WRF-Hydro system in the state of Pernambuco seeking to develop a management tool to simulate rainfall, reservoir management, and flood forecasting. In the [13] they also employed WRF-Hydro in the northeastern region of Brazil called MATOPIBA to simulate the flows of water bodies in the region and also develop a web tool for the application of the model. 
The WRF-Hydro model has become a major ally in water resource management and hydrometeorological modeling, as demonstrated in [14]. This model has a great potential to study small and medium hydrographic basins that tend to have lower availability of data and hydrometeorological stations. However, it is important to keep in mind that the workflow for this system is based on pre-processing, processing, and post-processing phases. These steps require the handling of large amounts of input data with high spatial resolution, such as topography, land use, and occupation, information from lakes and rivers, among others, and this results in many results to be analyzed. Additionally, the model requires a robust computer structure for its processing.

These WRF-Hydro requirements often limit its application, as the computer structure is not an easily accessible resource, especially for the reality of Brazil, surface data in high resolution, data measured for model validation are not always available. Because of these computational difficulties, there is the possibility of applying artificial intelligence (AI) techniques to facilitate the processing of WRF-Hydro, seeking an improvement of the predictions made by modeling and post-processing, where it is possible to train the network with the measured data and even history of the WRFHydro itself to have a faster forecast and less computational computing costs. At this point, it is important to point out that Al has already been applied in the WRF model without the coupling of the water module, as [15-20] to improve the modeled results and predictability of future data. However, the application of Al together with WRFHydro has still been developed, as in the studies of [21, 22]. A major advantage expected in the use of Al to facilitate the processing and post-processing of WRFHydro is the lower demand for computational resources and greater speed of forecasting water body flows when the network is trained.

The faster forecasting with the use of $\mathrm{Al}$ will help management and better characterization of water resources. In the covid-19 pandemic period, indicators such as levels of contamination of wastewater/water bodies by SARS-CoV-2 can identify regions more contaminated by the virus, as exposed [23]. In Brazil, unfortunately, much of the domestic sewage is added directly to the water bodies. About $54 \%$ of Brazil's sewage is collected and only $69 \%$ of the sewage collected is treated [24] and, consequently, the Sars-CoV-2 virus is also released into water bodies. Studies such as [25-27] identify the virus in wastewater and, the work developed in Belo Horizonte [28], Brazil, also identified the virus in the sewage system. The paper [23] also highlight 
that the monitoring of wastewater is a good indicator for contamination levels of SarsCoV-2. However, [26] and laboratory tests are not sufficient to predict the increase or decrease in the level of infection.

Additionally, the [29] hydrological variables (lake area, river length, precipitation, and volume of water resources) with the number of cases confirmed by Sars-CoV-2. The authors concluded that hydrological variables have a significant correlation in the prediction of COVID-19 incidences, suggesting that water transmission of Sars-CoV-2 is a source of virus spread, and may pose a threat to public health. However, [30] report that the transmission of Sars-CoV-2 through contact with contaminated waters and contaminated feces is uncertain and needs further studies.

The study[31] emphasized the use of epidemiological tools, such as WastewaterBased Epidemiology (WBE) to assist in management using Sars-CoV-2 markers in wastewater to trace the profile of contamination in cities and assist in mitigating disease outbreaks. It should be noted that, even though it is an important tool, monitoring of water bodies requires sampling campaigns and specific laboratory analyses to determine the level of water contamination, which can be costly, and personnel requires training. Given these difficulties, the application of WRF-Hydro coupled with Al can serve as an auxiliary rapid response tool to understand the dynamics, displacement, and reach of Sars-CoV-2 in water bodies, assisting in the management not only of water resources but also in the management of the pandemic.

Then, this study aims to analyze the feasibility of a computational tool for simulation, monitoring, and analysis of water predictability using WRF-Hydro and $\mathrm{Al}$ in the MATOPIBA region (Maranhão-Tocantins-Piauí-Bahia), where the management of water resources has strong socioeconomic interest for the Brazilian government.

\section{Methodology}

\subsection{Study area}

The area under study is the MATOPIBA region, an area demarcated of Brazil: Maranhão, Tocantins, Piauí and Bahia. The states that make up the MATOPIBA region have a large volume of freshwater available in Brazil, especially the Northwest Atlantic, Parnaíba, Tocantins-Araguaia, and São Francisco basins. 
Figure 1 - Study area

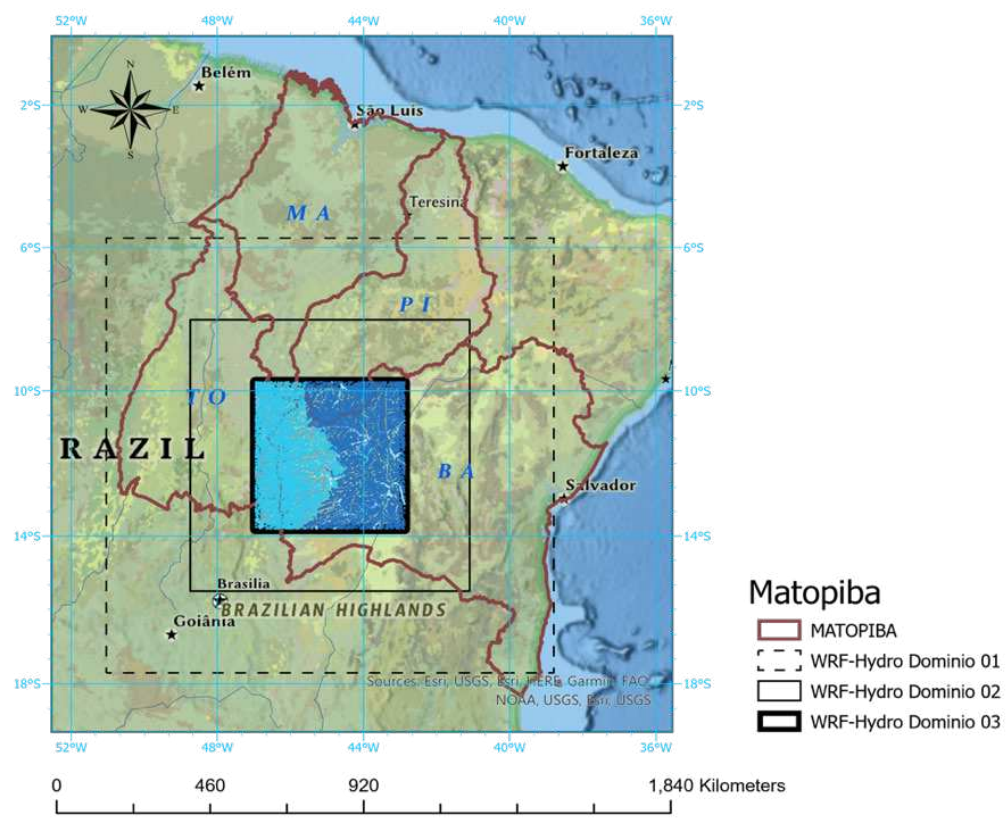

The state of Maranhão is in the northeast of Brazil and its vegetation covers the Amazon forest, savanna, and caatinga. The Tocantins located is in the central region of Brazil, being bounded to the west by the Araguaia River and in the center by the Tocantins River, with an economy composed basically of agriculture[32-35]. Piauí is inserted in the Brazilian Northeast, and its economy is focused on the industry (chemistry, textile, beverage, agriculture, and livestock). Bahia is also in the Northeast region and its economy is composed of agriculture, industry, mining, tourism, energy (oil and gas and renewables), and services [32-35].

The scenario presented is a region with great agricultural quality and that requires the exploitation of land use and water resources and which, in turn, has adjacent regions inhabited by people who make up the region's workforce and who also make use of the water resources available in the region. Therefore, evaluating the feasibility of a tool for monitoring and analyzing water predictability to manage these resources and forecasting droughts/floods, in addition to verifying the level of contamination of the region by Sars-CoV-2, is extremely important.

\subsection{Hydrometeorological modeling with WRF-Hydro system}

As simulations were performed using the WRF-Hydro hydrometeorological modeling system. Modeling coupling the high-resolution hydrological model to a thin-scale 
weather model within a single system. This reduces the uncertainties associated with the spatial distribution and precipitation volume, demonstrating the adequate predictive potential for surface runoff, flow forecasting, and flooding.

The modeling was divided into two parts (meteorological and hydrological). The weather model was configured in three nested degrees with a resolution of $9 \mathrm{~km}, 3 \mathrm{~km}$, and $1 \mathrm{~km}$, according to Figure 1 above. Figure 2 shows domain D03 of the WRF-Hydro system.

Figure 2 - Location of the domain of interest with water flows

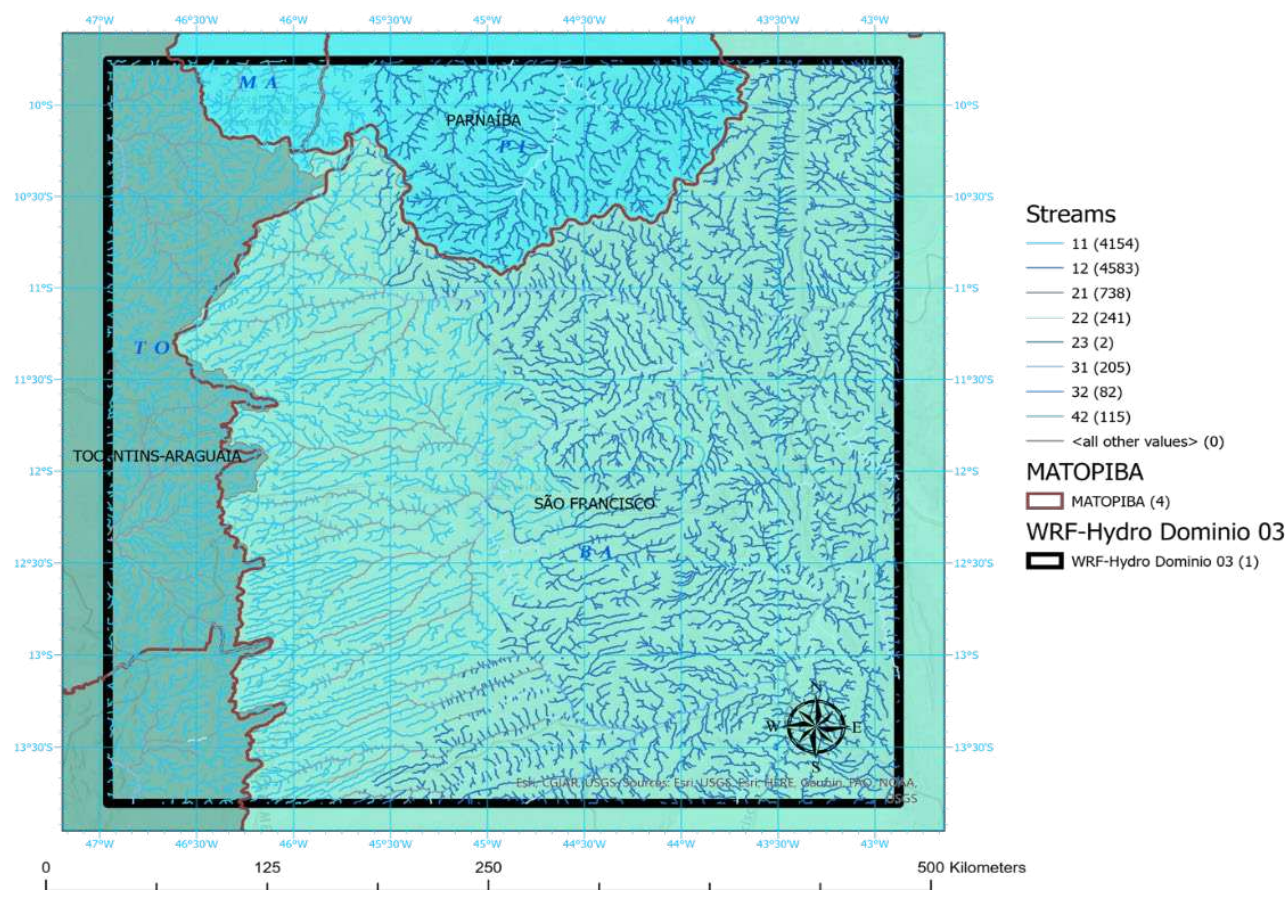

The domain of interest (D03) has a horizontal resolution of $1 \mathrm{~km}$ in a category of 448 x 454 cells, using geoprocessing tools for resizing grade to $250 \mathrm{~m}$ in the water scope. An overview of spatial settings is shown in Table 1.

Table1 - Configuration of domains.

\begin{tabular}{cccc}
\hline Domain & D01 & D02 & D03 \\
\hline Horizontal Resolution & $9 \mathrm{~km}$ & 1.6 miles & $1 \mathrm{~km}$ \\
\hline Number of cells & $150 \times 150$ & $280 \times 280$ & $448 \times 454$ \\
\hline Domain size & $1350 \times 1350 \mathrm{~km}$ & $840 \times 840 \mathrm{~km}$ & $448 \times 454 \mathrm{~km}$ \\
\hline
\end{tabular}


The simulation was performed using the WRF-ARW core, version 3.9.1, with initialization at 12 PM (UTC) on March 10, 2019, extending until 18 PM (UTC) on March 20, 2019 (246 $\mathrm{h}$ of the simulation). This simulation aimed to generate the preliminary data necessary for geoprocessing in the ArcGIS application. As initial and contour conditions used in the simulations come from the global atmospheric model GDASFNL(Global Data Assimilation System Final Analysis)of the NCEP (National Center for Environmental Forecasting), with horizontal resolutionof $0.25^{\circ} \times 0.25^{\circ}$ temporal resolution of 6 hours. Land use and occupation topography data are provided by the USGS (United States Geological Survey)with a resolutionof30 s [36].

A growing trend of the use of unidirectional or two-way hydrometeorological modeling systems, indicating the importance of integrated atmospheric, geological, and hydrological modeling tools. Typical studies use the WRF model and hydrological models, such as the WRF-Hydro model [14]. Due to its robust architecture, the WRFHydro system represents the state of the art in hydrometeorological modeling, whether in uncoupled or coupled mode. Figure 3 shows the representation of how models are integrated.

Figure 3 - Structure of the WRF-Hydro system given the physical aspects related to meteorology and the type of coupling.

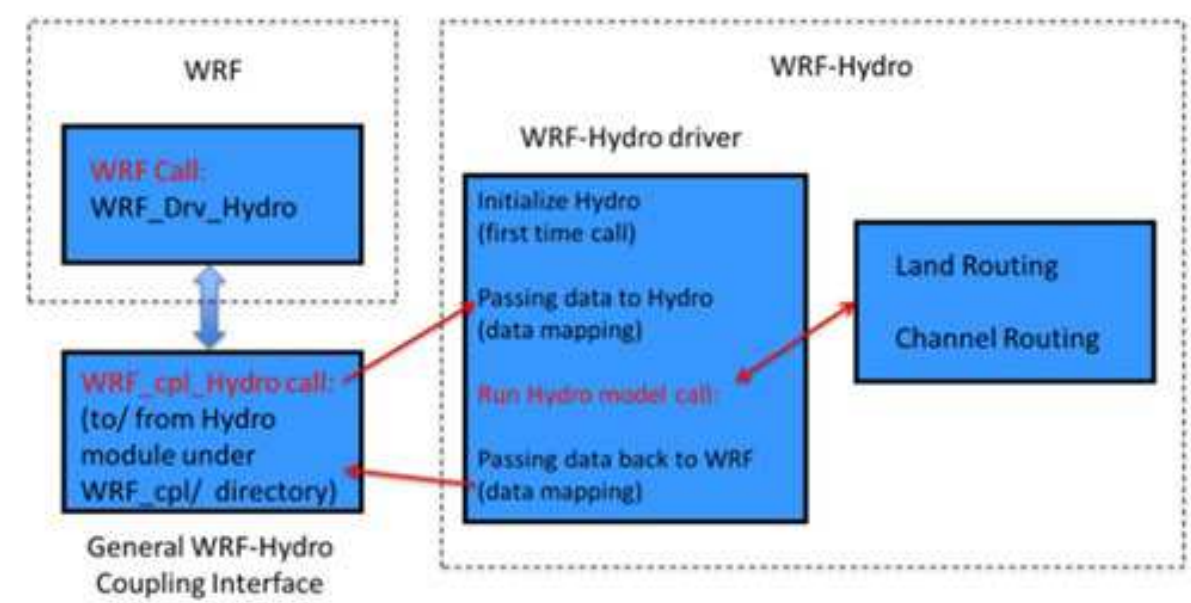

Source: An adapted figure of [3]

After preprocessing with WRF, as shown in Figure 3, the intermediate files required for processing data with ArcGIS are obtained. It is important to highlight that ArcGIS was also developed for the characterization of drainage systems (stream networks, watersheds, floodplain characteristics) and model integration. Its structure has extensibility through tools composed of modules or scripts written in Python and are 
integrable to the central module of ArcGIS. ArcGIS Isa software package for the development and manipulation of vector and matrix information for the use and management of thematic bases. ArcGIS provides a GIS (geographic information System) environment with a range of tools in an integrated way and good software usability. Geoprocessing can be understood as the technical and conceptual link of the tools for capturing, storing, processing data, and presenting georeferenced spatial information.

The WRF-Hydro GIS preprocessing toolkit was designed by NCAR[37] to facilitate the process of derivation of input files and WRF-Hydro parameters from commonly available geospatial data products, such as digital elevation models, land use and occupancy, geospatial metadata to support georeferencing of relevant WRF-Hydro model output files, and shapefiles to help visualize model components.

WRF-Hydro GIS preprocessing tools are designed to function as an additional Python toolbox in The ArcGIS ESRI software. The specific operating system and software requirements are covered by the complete documentation of the WRF-Hydro GIS preprocessing toolkit [37].

As mentioned, it is noted that working with the WRF-Hydro system requires a series of steps that may present some complexity for researchers from different areas, but which are fundamental in the study of hydrological aspects of a hydrological basin. Information on the study of water is needed for decision-making in several studies, which are often scarce, preventing adequate management of water resources, as mentioned in the Hydrological Atlas of the Rio Grande river basin [33].

Thus, the construction of a web tool that minimizes the need to prepare specific computational codes, capable of integrating the execution steps of WRF-Hydro intuitively, is an alternative for engineers, scientists, and other professionals related to the hydrometeorology area. This allows them to develop their studies with quality equivalent to the conventional work of WRF-Hydro, without the need for possible assistance from a computer professional, thus stimulating the increase of research in this area and rewarding possible failures of hydrological monitoring of hydrological basins. 


\subsection{Hydrometeorological modeling with Al approach}

As agile neural networks that were considered for use in this solution are convolutional neural networks (CNN) and the recurrent network called Long Short-Term Memory (LSTM). A brief overview of these types of neural networks will be shown in this section.

\subsubsection{Convolutional Neural Networks (CNN)}

A CNN is a type of artificial neural network that applies filters to input data and has great learning power for spatial and even time relationships within the input data. Neural networks are computational models inspired by the central nervous system of an animal that can perform machine learning as well as pattern recognition. CNN can reduce the size of data through its filter or kernel-driven convolution operations in the convolution layer, which extracts high-level resources from the data. The kernel is the central component of the operating system of most computers, it serves as a bridge between applications and the actual processing of data done at the hardware level. Core responsibilities include managing system resources. In kernel convolution, the input is transformed based on the values of a filter.

$\mathrm{CNN}$ also has the pooling layer to reduce the necessary processing to network training. This layer is responsible for reducing the spatial size of the convolution step output. Examples of operations of this type are the maximum value (MaxPooling) and the average value (AvgPooling) in each fixed-size window. Then there is a layer responsible for leveling the output to a one-dimensional layer, the output of which is eventually submitted to the last part of CNN: one or more fully connected layers, or Multilayer Perceptron (MLP), which performed the final classification or regression task. Because of these characteristics, CNN's are widely used in the area of computer vision to perform tasks such as detecting objects in images [38]. Fully convolutional networks(Fully Convolutional Networks - FCN) are a type of convolutional neural network that does not have the final layer of MLP, being to extract the main characteristics of degrees from the data for use in subsequent layers, such as that in hybrid approaches.

\subsubsection{Long-term Neural Memory Networks (LSTM)}

LSTM networks are a special type of neural recurrent network that has been created as an approach to the problem of forgetting long-term dependencies common in 
recurrent neural networks. The LSTM network was first introduced by [39] since then many variants of this neural network have been created.

Figure 4 illustrates the structure of an LSTM cell, in which arrows represent the data flow, squares, point operations, and circles correspond to activation functions. The main part of an LSTM network is the state of the cell, which is an internal selective memory of the past, represented by the horizontal line that starts at $\mathrm{C}_{\mathrm{t}-1}$ and ends at $\mathrm{c}_{\mathrm{t}}$. The hidden state, represented by $h$, is the output of the LSTM cell.

Figure 4 - Structure of an LSTM cell.

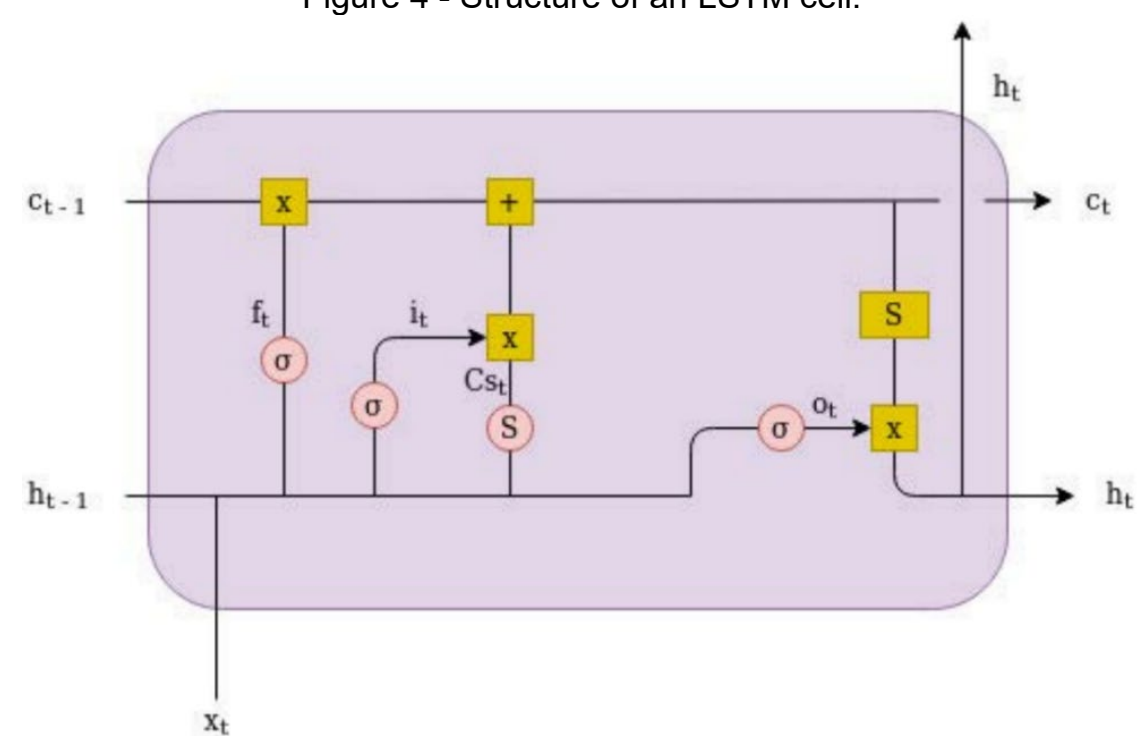

Source: An adapted figure of [38]

\section{RESULTS AND DISCUSSION}

3.1 WRF-Hydro and ArcGIS integrated by API in a web interface.

Based on the analyses carried out in a multidisciplinary research environment it was possible to obtain information about the quality, accuracy, and integration of WRFHydro tools with the respective integration modules in an HPC (High-Performance Computing) environment, ESRI ArcGIS as an independent layer, as well as a web interface.

From the non-intuitive processes in which this information was obtained, it is considered the proposal of the web interface. Some authors are highlighting the important characteristics that software usability offers us, associating the ease with which new users can initiate effective interaction and achieve maximum performance in tasks that are included in the context of $[40,41]$. 
From this perspective, an integration structure of WRF-Hydro and ArcGIS is presented through a web usability tool suitable for researchers or potential customers, through the visualization and operation of simulation processes, to monitor and perform predictability analyses of hydrometeorological cars in each region.

Figure 5 represents a DEM (Digital Elevation Model) with river flows in the upper view. Video 01 represents a DEM with river flows in an animation exposing more details about this micro basin. To access this animation, click the animation hyperlink or go to this URL (Video 01 https://youtu.be/oQiw9nHedtg).

Figure 5 - Flow of the Rio Grande DEM stream. Rio Grande DEM 3D
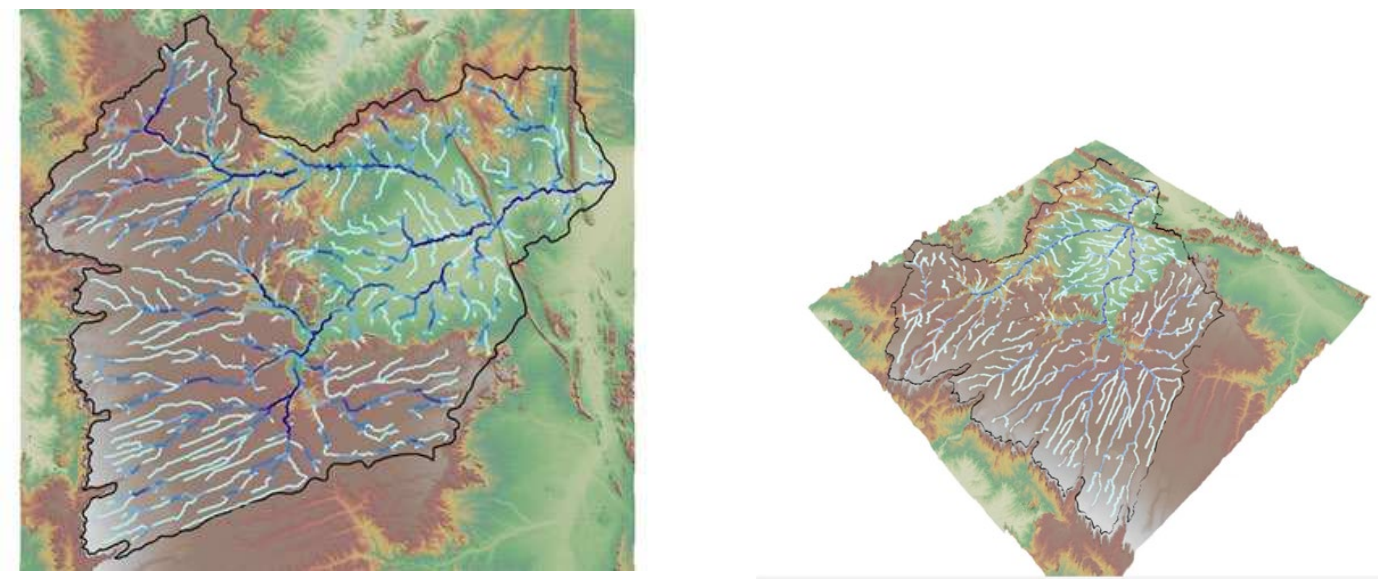

These results were generated with a multidisciplinary team with distinct functions, but which can be simplified into a single gis web tool, providing a single view of the dashboard designed based on software usability, using native integration as shown in Figure 6, through the Rest architecture) and SOAP protocol (Simple Object Access Protocol), through API(Application Programming Interface), developed in programming languages such as Java, .NET, or.

Figure 6 - ArcGIS Framework

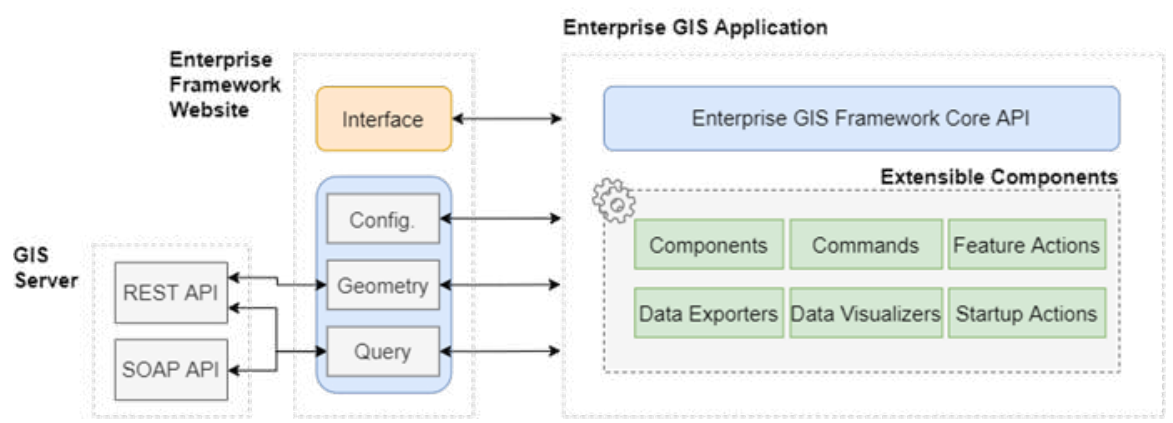

Source An adapted figure from [42] 
Figure 7 displays the WRF-Hydro Coupling of Coupled Model, which is commonly loaded in the HPC environment and which could be operated by automated Python scripts for simulation routines.

Figure 7 - WRF-Hydro Structure

Coupled Mode: Nowcast, Weather and Climate Models

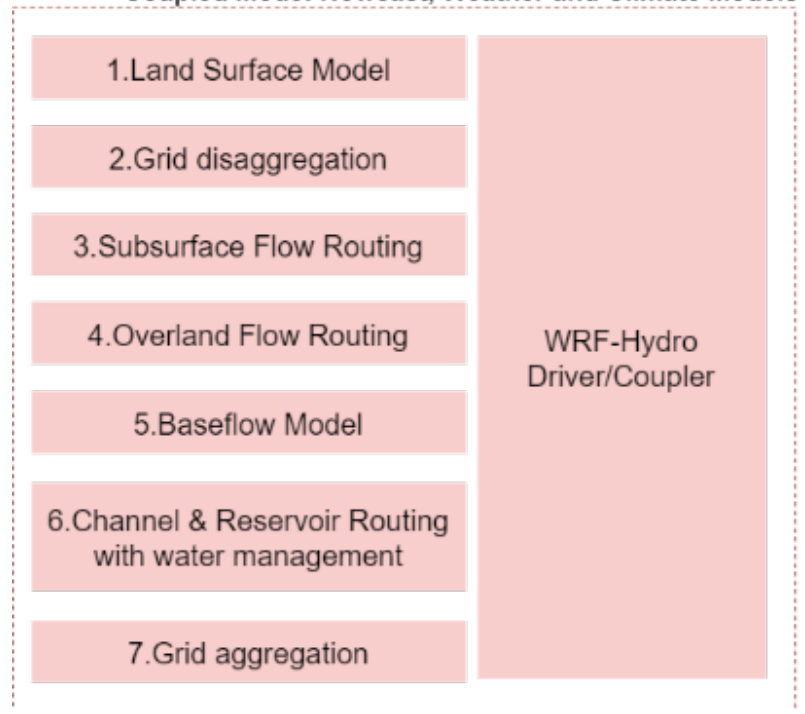

Source: An adapted figure from [3]

Figure 8 shows a representation of the logical integration of solutions through a GIS web tool. 
Figure 8 - WRF-Hydro, ArcGIS, and IA integration structure

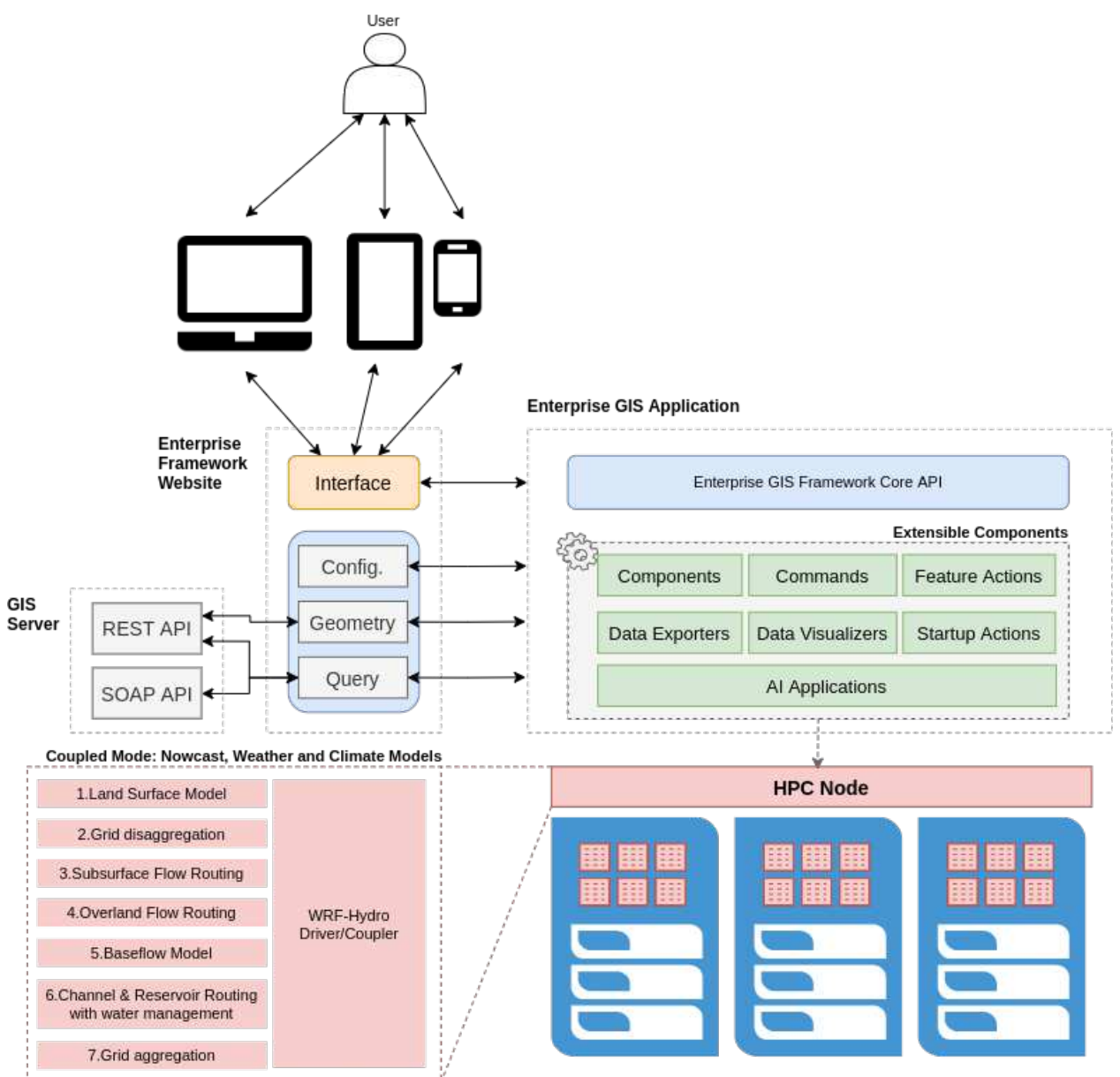

Source: An adapted figure $[3,42]$

\subsection{Al application module}

Although WRF-Hydro-related tools are considered state-of-the-art in the context of hydrometeorological modeling, some of the significant limitations are computational cost and simulation time required. Additionally, model calibration is an arduous task that requires good surface data and startup data, which is often scarce or not suitable for application in forecasting. Once the calibration has adjusted and the results become more stable, the model can be directed in a particular way to rescan the reliable results, within their respective limits. Thus, it is possible to provide greater accuracy, but there is still a considerable effort of configuration and may take a long period to obtain good results, being also restrictive to a defined period.

At this point, the application of $\mathrm{Al}$ algorithms arises to overcome part of these barriers. Good results have been found with applications of neural networks for simulations, in the short and medium-term, [38] and concentrations of pollutants [38], and can be 
extended to the field of hydrometeorology. These models will also be costly during the training process, but assuming a sufficiently large amount of data, with proper processing of features, can be generalized proving a good accuracy and not being restricted to a period. With this, it is possible to integrate an Al module into the proposed architecture in [43] containing previously trained models and the possibility of managing algorithms to perform validations and study of comparations between these approaches and the results of the WRF-Hydro model, in the short and mediumterm, proving knowledge for long-term evaluations, optimizing the time and cost of in. Besides, obtaining the results more systematically will serve as a basis for decisionmaking for river basin management and forecasting extreme events (droughts and floods) more efficiently and quickly. Also, the management of water bodies can help in the indicators of contamination for the Sars-CoV-2 pandemic, being an additional tool to the monitoring of wastewater and water bodies, especially that it concerns the association of pandemic indicators with the characteristics of the water body, crucial information that is modeled by WRF-Hydro and optimized by Al.

\section{Conclusion}

The research is being developed by an interdisciplinary group of researchers who are working on the execution of all the steps considered necessary in the hydrometeorological simulation of the MATOPIBA region. The geoprocessing of the region was completed by the means of ArcGIS, as presented, bringing partial results of the detailed information of the region, important for the next stages of the study. Besides, flow, precipitation, and other variables have already been obtained, proving the WRF-Hydro system as an efficient hydrometeorological simulation model. Thus, a system with Al tools is promising to reduce the computational cost and may be suitable for analysis of water bodies and possible indices of contagion evolution by Sars-Cov2 with monitoring and mitigation of the number of cases related to the current pandemic. A significant evolution has been made in the processing and application of WRF-Hydro and the group is still working on some steps to seek improvements in simulation accuracy through automated and efficient data calibration.

Therefore, with the consolidation of the described processes, we seek the implementation of the proposed solution, considered feasible to be implemented, given the significant number of steps required in monitoring and hydrometeorological carried 
out, in large part, by scholars not related to the area of computing. Thus, it is perceived, excellent perspectives for the use of Al enable a tool not limited to the traditional management of water resources, but also a solution capable of correlating water management with indicators of contamination of pandemics such as Covid19 that we currently face.

\section{Abbreviations}

Al: Artificial Intelligence

API: Application Programming Interface

ArcGIS: Geographic Information System

AvgPooling: Average pooling value

CNN: Convolutional Neural Networks

COVID-19: Coronavirus Disease 2019

cpl: Coupling Interface

Ct: $C$ represents the cell state at a given timestep $t$

DEM: Digital Elevation Model

Drv: Driver

D03: Domain 03

ESRI: Environmental Systems Research Institute

FCN: Fully Convolutional Networks

GDAS-FNL: Global Data Assimilation System Final Analysis

h: Hour

HPC: High Performance Computing

$\mathbf{h}_{\mathbf{t}}: \mathrm{H}$ represents the output of the LSTM block at a given timestep $\mathrm{t}$

MATOPIBA: Acronym for Maranhão - Tocantins - Piauí - Bahia

MaxPooling: Maximum polling value

MLP: Multilayer Perceptron

NASA: National Aeronautics and Space Administration

NCAR: National Center for Atmospheric Research

NCEP - National Center for Environmental Prediction

LSTM: Long Short-Term Memory Neural Networks

Python: Programming language Python 
REST: Representational State Transfer

Sars-CoV-2: Severe acute respiratory syndrome coronavirus 2

s: seconds

SIG: Geographic Information System

SOAP: Simple Object Access Protocol

USGS: United States Geological Survey

UTC: Coordinated Universal Time

WBE: Wastewater-Based Epidemiology

WRF: Weather Research and Forecasting

WRF-Hydro: Weather Research and Forecasting - Hydro

\section{Declarations}

\section{Availability of supporting data}

All data generated or analyzed during this study are included in this published article.

\section{Competing interests}

The authors declare that they have no competing interests.

\section{Funding}

No funding.

\section{Author's contributions}

\section{JÚNIOR, José Roberto Dantas da Silva}

He was responsible for the team leadership, the literature review and the major contributor for the manuscript, regarding WRF-Hydro, GIS tools, Simulations, and system integrations.

\section{PEDRUZZI, Rizzieri}

He was responsible for the literature review and the major contributor for the manuscript, regarding WRF-Hydro, Simulations, and Sars-CoV2 references. 


\section{SOUZA, Filipe Milani de}

He was responsible for the literature review and the major contributor for the manuscript, regarding WRF-Hydro, and Artificial Intelligence references and analyses.

\section{FERRAZ, Patrick Silva}

He was responsible for the literature review and the major contributor for the manuscript, regarding coding analyses, systems integrations, and Artificial Intelligence references and analyses.

\section{SILVA, Daniel Guimarães}

He was responsible for the literature review and the major contributor for the manuscript, regarding WRF-Hydro, GIS tools references and analyses.

\section{VIEIRA, Carolina Sacramento}

He was responsible for the literature review and the major contributor for the manuscript, regarding WRF-Hydro references and analyses.

\section{MORAES, Marcelo Romero de}

He was responsible for the literature review and the major contributor for the manuscript, regarding simulations, WRF, WRF-Hydro references and analyses.

\section{NASCIMENTO, Erick Giovani Sperandio}

He was responsible for the literature review and the major contributor for the manuscript, regarding artificial intelligence references and analyses.

\section{MOREIRA, Davidson Martins}


He was responsible for the team ownership, the literature review, and the major contributor for the manuscript, regarding WRF, WRF-Hydro, Numerical Weather Prediction, manuscript review and corrections.

\section{All authors}

Read and approved the final manuscript.

\section{Acknowledges}

The authors thanks SENAI CIMATEC and the Bahia State Research Support Foundation (FAPESB).

\section{Authors Details}

${ }^{1}$ Manufacturing and Technology Integrated Campus - SENAI CIMATEC - Salvador -

BA, Brazil. ${ }^{2}$ Renewables Energies Campus - Pampa's Federal University - Bagé - RS, Brazil.

\section{References}

1. United T, World N, Development W (2020) WWAP (UNESCO World Water Assessment Programme), 2019, United Nations World Water Development Report 2020: Water and Climate Change. UNESCO, Paris, p 325

2. Silva RR, Ribeiro CJN, Moura TR, Santos MB, Santos AD, Tavares DS, Santos PL (2021) Basic sanitation: a new indicator for the spread of COVID-19? Trans R Soc Trop Med Hyg 1-9 . https://doi.org/10.1093/trstmh/traa187

3. Gochis DJ, Barlage M, Dugger A, Fitzgerald K, Karsten L, Mcallister M, Mccreight J, Mills J, Rafieeinasab A, Read L, Sampson K, Yates D, Yu W (2020) The NCAR WRF-Hydro Modeling System V5 Technical Description. NCAR Tech Note 107

4. Abbaszadeh P, Gavahi K, Moradkhani H (2020) Multivariate remotely sensed and in-situ data assimilation for enhancing community WRF-Hydro model forecasting. Adv Water Resour 145:103721 https://doi.org/10.1016/j.advwatres.2020.103721

5. Wehbe Y, Temimi M, Weston M, Chaouch N, Branch O, Schwitalla T, Wulfmeyer V, Zhan X, Liu J, Al Mandous A (2019) Analysis of an extreme weather event in 
a hyper-arid region using WRF-Hydro coupling, station, and satellite data. Nat Hazards Earth Syst Sci 19:1129-1149 . https://doi.org/10.5194/nhess-19-11292019

6. Lahmers TM, Gupta H, Castro CL, Gochis DJ, Yates D, Dugger A, Goodrich D, Hazenberg $P$ (2019) Enhancing the structure of the WRF-hydro hydrologic model for semiarid environments. J Hydrometeorol 20:691-714. https://doi.org/10.1175/JHM-D-18-0064.1

7. Lin P, Rajib MA, Yang Z-L, Somos-Valenzuela M, Merwade V, Maidment DR, Wang Y, Chen L (2018) Spatiotemporal Evaluation of Simulated Evapotranspiration and Streamflow over Texas Using the WRF-Hydro-RAPID Modeling Framework. JAWRA J Am Water Resour Assoc 54:40-54. https://doi.org/10.1111/1752-1688.12585

8. Lin P, Yang ZL, Gochis DJ, Yu W, Maidment DR, Somos-Valenzuela MA, David $\mathrm{CH}$ (2018) Implementation of a vector-based river network routing scheme in the community WRF-Hydro modeling framework for flood discharge simulation. Environ Model Softw 107:1-11 . https://doi.org/10.1016/j.envsoft.2018.05.018

9. Arnault J, Rummler T, Baur F, Lerch S, Wagner S, Fersch B, Zhang Z, Kerandi N, Keil C, Kunstmann H (2018) Precipitation sensitivity to the uncertainty of terrestrial water flow in WRF-Hydro: An ensemble analysis for central Europe. J Hydrometeorol 19:1007-1025 . https://doi.org/10.1175/JHM-D-17-0042.1

10. Silver M, Karnieli A, Ginat H, Meiri E, Fredj E (2017) An innovative method for determining hydrological calibration parameters for the WRF-Hydro model in arid regions. Environ Model Softw 91:47-69 https://doi.org/10.1016/j.envsoft.2017.01.010

11. Kerandi N, Arnault J, Laux P, Wagner S, Kitheka J, Kunstmann H (2018) Joint atmospheric-terrestrial water balances for East Africa: a WRF-Hydro case study for the upper Tana River basin. Theor Appl Climatol 131:1337-1355 . https://doi.org/10.1007/s00704-017-2050-8

12. White DD, Lawless KL, Vivoni ER, Mascaro G, Pahle R, Kumar I, Coli P, Castillo RM, Moreda F, Asfora M (2019) Co-Producing Interdisciplinary Knowledge and Action for Sustainable Water Governance: Lessons from the Development of a Water Resources Decision Support System in Pernambuco, Brazil. Glob Challenges 3:1800012 . https://doi.org/10.1002/gch2.201800012

13. Silva Júnior JRD da, Souza FM de, Silva DG, Ferraz PS, Moares MR de, Schäfer AG, Nascimento EGS, Moreira DM (2020) FEASIBILITY ANALYSIS ON THE CONSTRUCTION OF A SOLUTION FOR MONITORING AND HYDROMETEOROLOGICAL FORECASTING. In: Blucher Engineering Proceedings. Editora Blucher, São Paulo, pp 585-593

14. Sun M, Li Z, Yao C, Liu Z, Wang J, Hou A, Zhang K, Huo W, Liu M (2020) Evaluation of flood prediction capability of the WRF-hydro model based on multiple forcing scenarios. Water (Switzerland) 12: https://doi.org/10.3390/w12030874

15. Zhao J, Guo Y, Xiao X, Wang J, Chi D, Guo Z (2017) Multi-step wind speed and power forecasts based on a WRF simulation and an optimized association 
method.

Appl Energy

https://doi.org/10.1016/j.apenergy.2017.04.017

197:183-202

16. Sayeed A, Choi Y, Jung J, Lops Y, Eslami E, Khan Salman A (2020) A Deep Convolutional Neural Network Model for improving WRF Forecasts

17. Shirali E, Nikbakht Shahbazi A, Fathian H, Zohrabi N, Mobarak Hassan E (2020) Evaluation of WRF and artificial intelligence models in short-term rainfall, temperature and flood forecast (case study). J Earth Syst Sci 129: . https://doi.org/10.1007/s12040-020-01450-9

18. Santos IG da S, Lyra RF da F, Silva Júnior RS da (2020) Comparativo de Prognósticos da Velocidade do Vento Utilizando Modelo WRF e Rede Neural Artificial. Rev Bras Meteorol 35:1017-1027 . https://doi.org/10.1590/010277863550103

19. Teixeira RS, Santos Conterato F, Maria P, Dias A, Kaore $Y$, Kitagawa L, Martins Moreira D, Giovani E, Nascimento S VI INTERNATIONAL SYMPOSIUM ON INNOVATION AND TECHNOLOGY (SIINTEC) HYBRID MODEL OF WIND SPEED PREDICTION IN SHORT TIME RANGE USING WRF AND ARTIFICIAL NEURAL NETWORKS MODELO HÍBRIDO DE PREVISÃO DE VELOCIDADE DO VENTO A CURTO PRAZO UTILIZANDO WRF E REDES NEU

20. Srivastava PK, Islam T, Gupta M, Petropoulos G, Dai Q, Srivastava PK, Gupta M, Petropoulos G, Dai Q (2015) WRF Dynamical Downscaling and Bias Correction Schemes for NCEP Estimated Hydro-Meteorological Variables. Water Resour Manag 29:2267-2284 . https://doi.org/10.1007/s11269-015-0940z

21. Rahman M, Nearing G S. (2019) Communicating ML-based Hydrological Models Across Disciplines. In: AGU Fall Meeting Abstracts. pp PA21B-1132

22. Cho K, Kim Y (2019) Streamflow prediction combining WRF-Hydro modelling with machine learning. In: AGU Fall Meeting Abstracts. pp H31E-07

23. Farkas K, Hillary LS, Malham SK, McDonald JE, Jones DL (2020) Wastewater and public health: the potential of wastewater surveillance for monitoring COVID19. Curr. Opin. Environ. Sci. Heal. 17:14-20

24. Von Sperling M (2016) Urban wastewater treatment in Brazil

25. Street R, Malema S, Mahlangeni N, Mathee A (2020) Wastewater surveillance for Covid-19: An African perspective. Sci Total Environ 743:140719 . https://doi.org/10.1016/j.scitotenv.2020.140719

26. Polo D, Quintela-Baluja M, Corbishley A, Jones DL, Singer AC, Graham DW, Romalde JL (2020) Making waves: Wastewater-based epidemiology for COVID19 - approaches and challenges for surveillance and prediction. Water Res 186:116404 . https://doi.org/10.1016/j.watres.2020.116404

27. Randazzo W, Cuevas-Ferrando E, Sanjuán R, Domingo-Calap P, Sánchez G (2020) Metropolitan wastewater analysis for COVID-19 epidemiological surveillance. Int J Hyg Environ Health 230:113621. https://doi.org/10.1016/j.ijheh.2020.113621

28. UFMG (2021) UFMG - Universidade Federal de Minas Gerais - Taxa do 
coronavírus nos esgotos de $\mathrm{BH}$ é quase duas vezes a do período mais crítico da pandemia. https://ufmg.br/comunicacao/noticias/taxa-do-coronavirus-nosesgotos-de-bh-e-quase-duas-vezes-a-do-periodo-mais-critico-da-pandemia. Accessed 15 Mar 2021

29. Wang J, Li W, Yang B, Cheng X, Tian Z, Guo H (2020) Impact of hydrological factors on the dynamic of COVID-19 epidemic: A multi-region study in China. Environ Res 110474 . https://doi.org/10.1016/j.envres.2020.110474

30. Elsamadony M, Fujii M, Miura T, Watanabe T (2021) Possible transmission of viruses from contaminated human feces and sewage: Implications for SARSCoV-2. Sci Total Environ 755:142575 https://doi.org/10.1016/j.scitotenv.2020.142575

31. Daughton CG (2020) Wastewater surveillance for population-wide Covid-19: The present and future. Sci. Total Environ. 736:139631

32. Moreira MC, Santos F da R dos S, Silva DD (2013) INVENTÁRIO DIGITAL DAS ESTAÇÕES FLUVIOMÉTRICAS E PLUVIOMÉTRICAS DA BACIA DO RIO GRANDE. Simpósio Bras Recur Hídricos 7

33. Castro M, Demetrius M, Da Silva D (2010) Atlas Hidrológico da Bacia Hidrográfica do Rio Grande. Barreiras, Bahia

34. Pitta FT, Vega GC, Barbosa S (2017) IMPACTOS DA EXPANSÃO DO AGRONEGÓCIO NO MATOPIBA: COMUNIDADES E MEIO AMBIENTE. ActionAid, Rede Soc. Justiça e Direitos Humanos, Ford Found. 82

35. Salomon (2020) Quem Disputa O Matopiba? Interesses E Sustentabilidade Na Fronteira Agrícola Quem Disputa O Matopiba? Interesses E. UNB

36. NCEP NC for EP, Service NW, NOAA/U.S. Department of Commerce (2015) NCEP GDAS/FNL 0.25 Degree Global Tropospheric Analyses and Forecast Grids. Research Data Archive at the National Center for Atmospheric Research, Computational and Information Systems Laboratory. In: https://doi.org/10.5065/D65Q4T4Z. https://rda.ucar.edu/datasets/ds083.3/. Accessed 10 Mar 2021

37. Sampson K, Gochis D (2020) WRF Hydro GIS Pre-Processing Tools, Version 5.1.1. Boulder, Colorado

38. Junior ASR, Nascimento EGS, Moreira DM (2020) Assessing recurrent and convolutional neural networks for tropospheric ozone forecasting in the region of vitória, brazil. WIT Trans Ecol Environ 244:101-112. https://doi.org/10.2495/AIR200091

39. Aksoy A, Ertürk YE, Erdoğan S, Eyduran E, Tariq MM (2018) Estimation of honey production in beekeeping enterprises from eastern part of Turkey through some data mining algorithms. Pak J Zool 50:2199-2207. https://doi.org/10.17582/journal.pjz/2018.50.6.2199.2207

40. Ballatore A, McClintock W, Goldberg G, Kuhn W (2020) Towards a usability scale for participatory GIS. Springer International Publishing

41. Ian N. Gregory, Paul S. Ell (2007) Historical GIS Technologies, Methodologies, and Scholarship. Cambridge University Press, Cambridge, UK 
42. INTERDEV (2021) High-Level Framework Architecture. In: http://interdev.dot.state.fl.us/wiki/GisFramework.MainPage.ashx.

https://interdev.dot.state.fl.us/wiki/GisFramework.MainPage.ashx. Accessed 10 Mar 2021

43. Roberto J, Júnior S, Milani F, Souza D, Guimarães D (2020) FEASIBILITY ANALYSIS ON THE CONSTRUCTION OF A SOLUTION. Blucher Eng Proc 7:8 . https://doi.org/10.5151/siintec2020-FEASIBILITYANALYSIS 


\section{Figures}

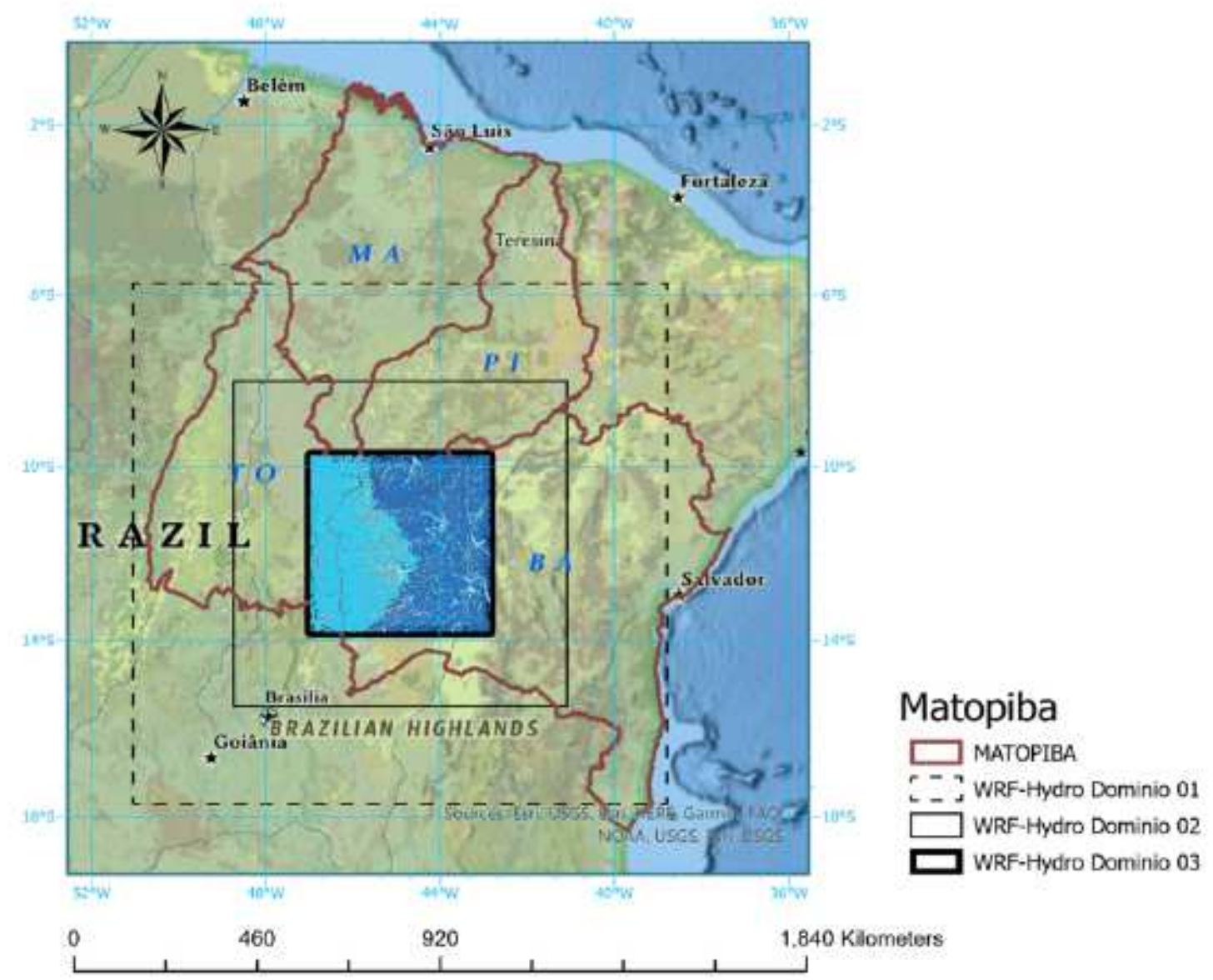

\section{Figure 1}

Study area Note: The designations employed and the presentation of the material on this map do not imply the expression of any opinion whatsoever on the part of Research Square concerning the legal status of any country, territory, city or area or of its authorities, or concerning the delimitation of its frontiers or boundaries. This map has been provided by the authors. 


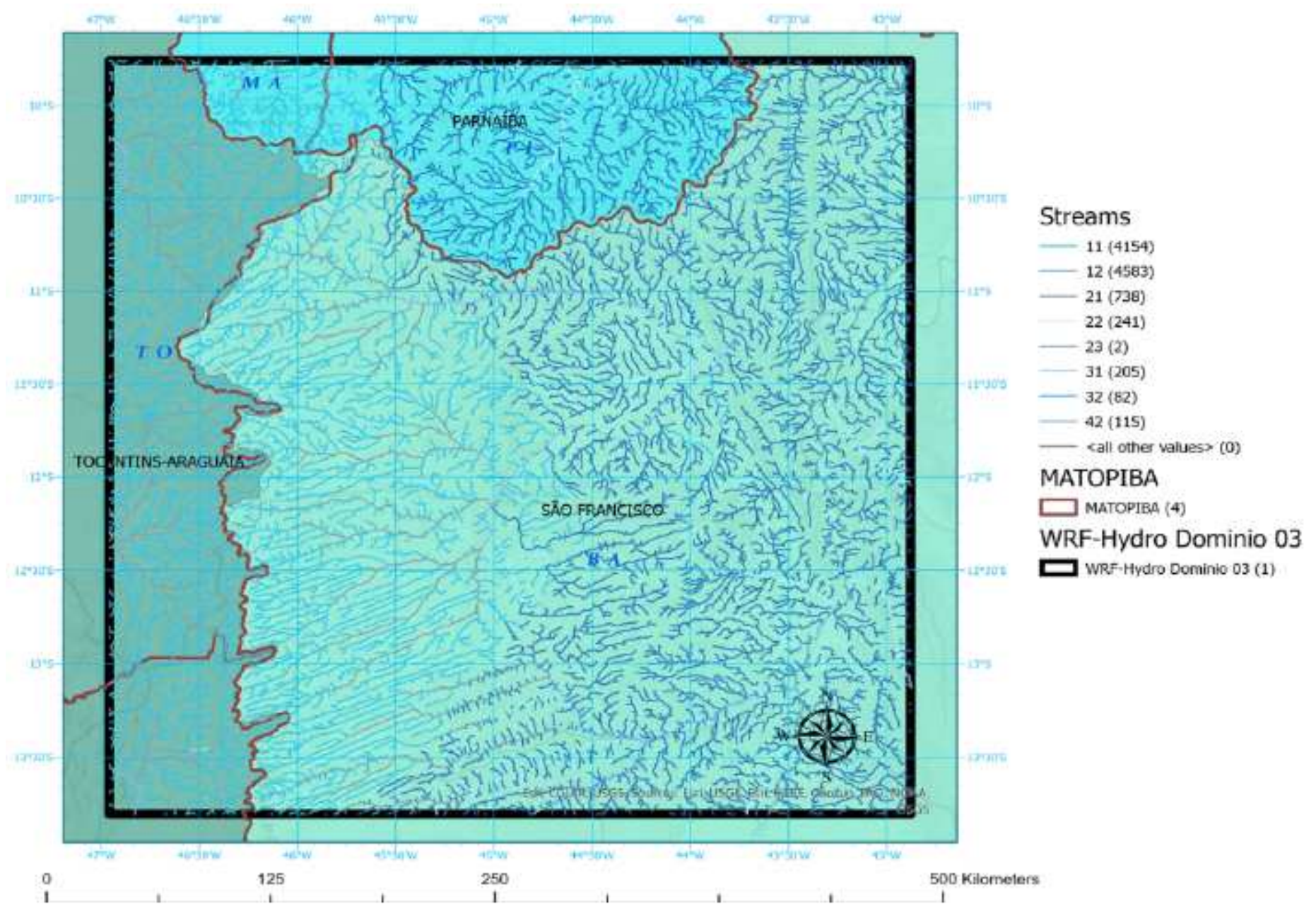

Figure 2

Location of the domain of interest with water flows Note: The designations employed and the presentation of the material on this map do not imply the expression of any opinion whatsoever on the part of Research Square concerning the legal status of any country, territory, city or area or of its authorities, or concerning the delimitation of its frontiers or boundaries. This map has been provided by the authors. 


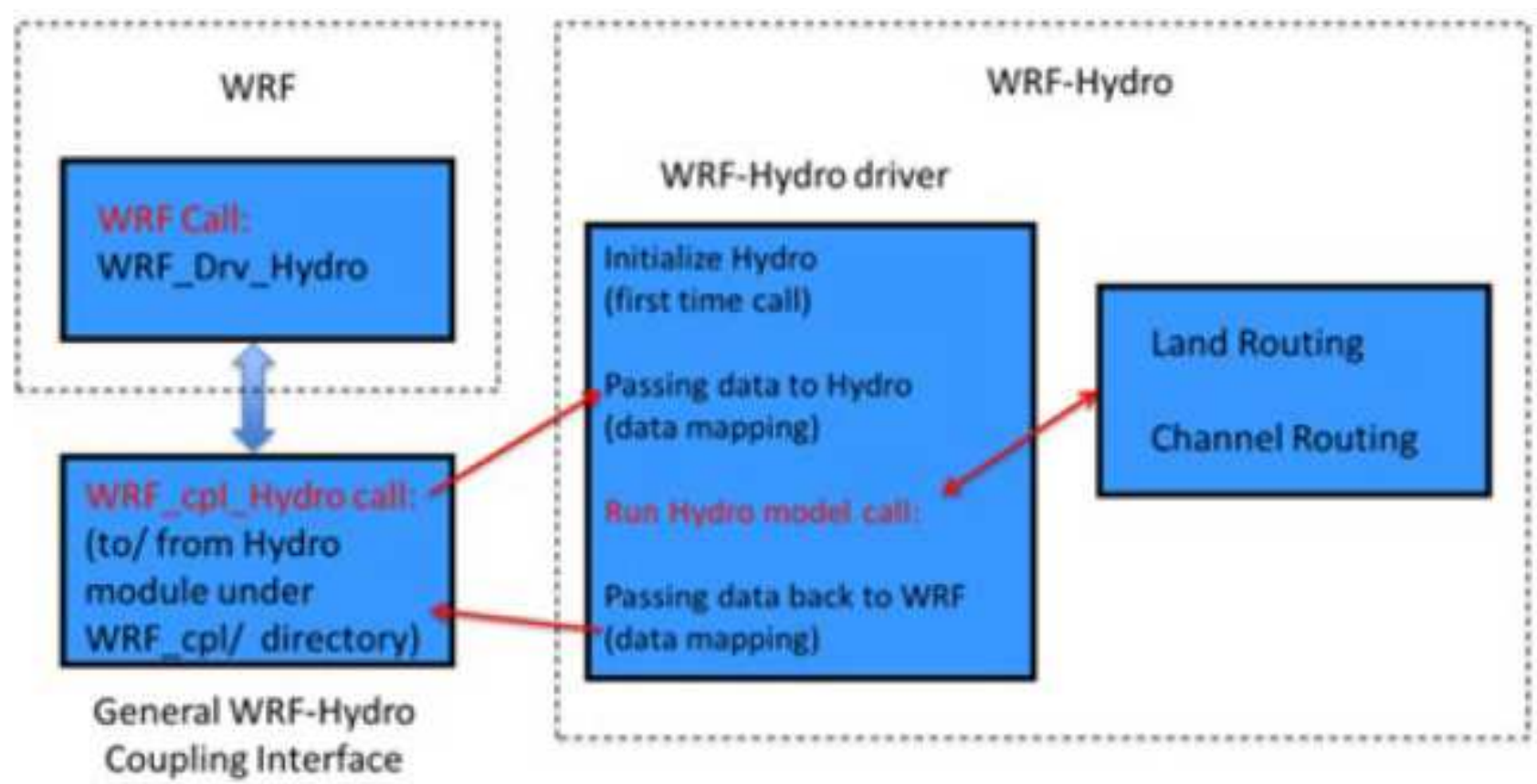

Source: An adapted figure of [3]

Figure 3

Structure of the WRF-Hydro system given the physical aspects related to meteorology and the type of coupling.

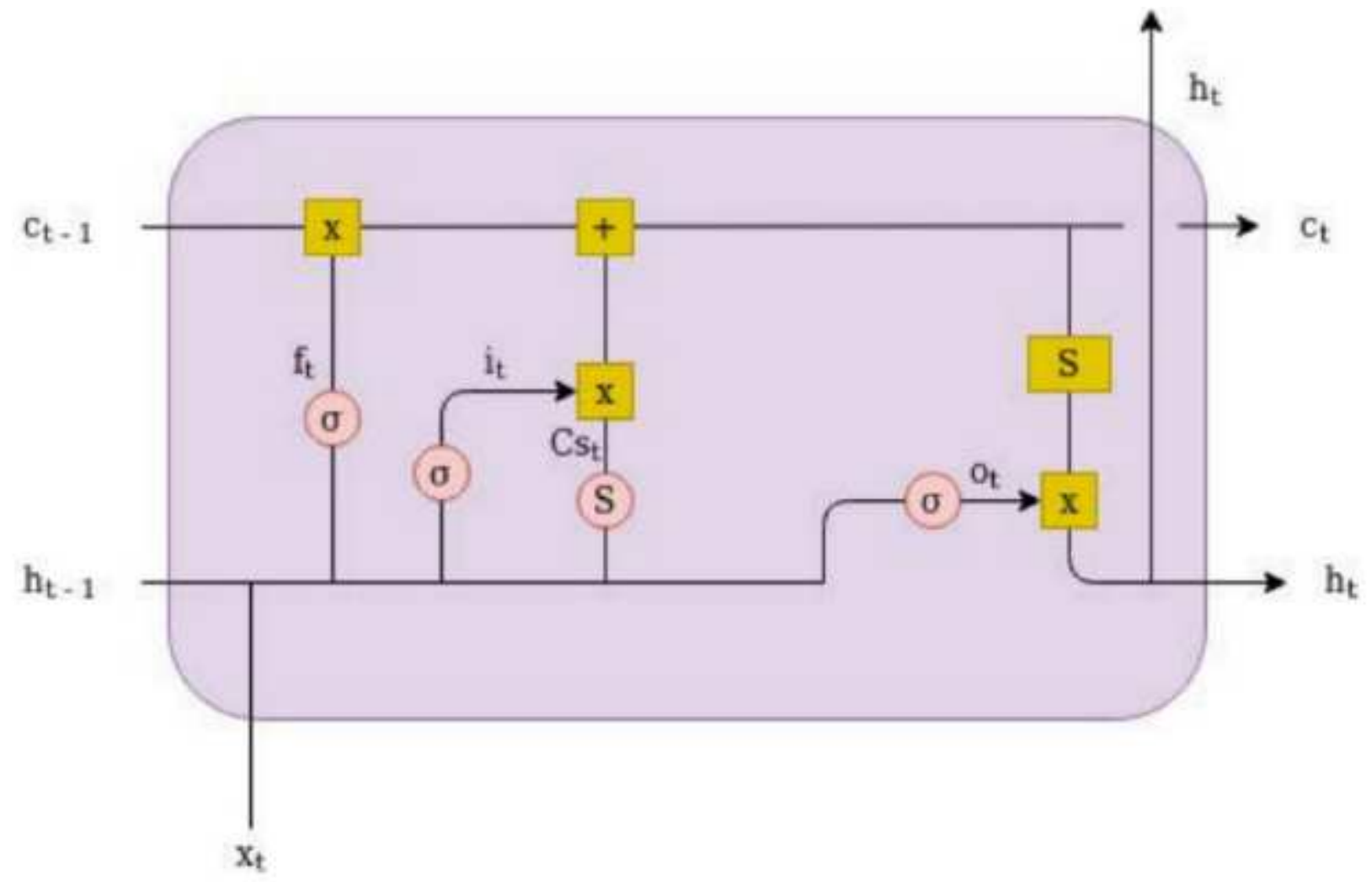

Source: An adapted figure of [38] 
Structure of an LSTM cell.
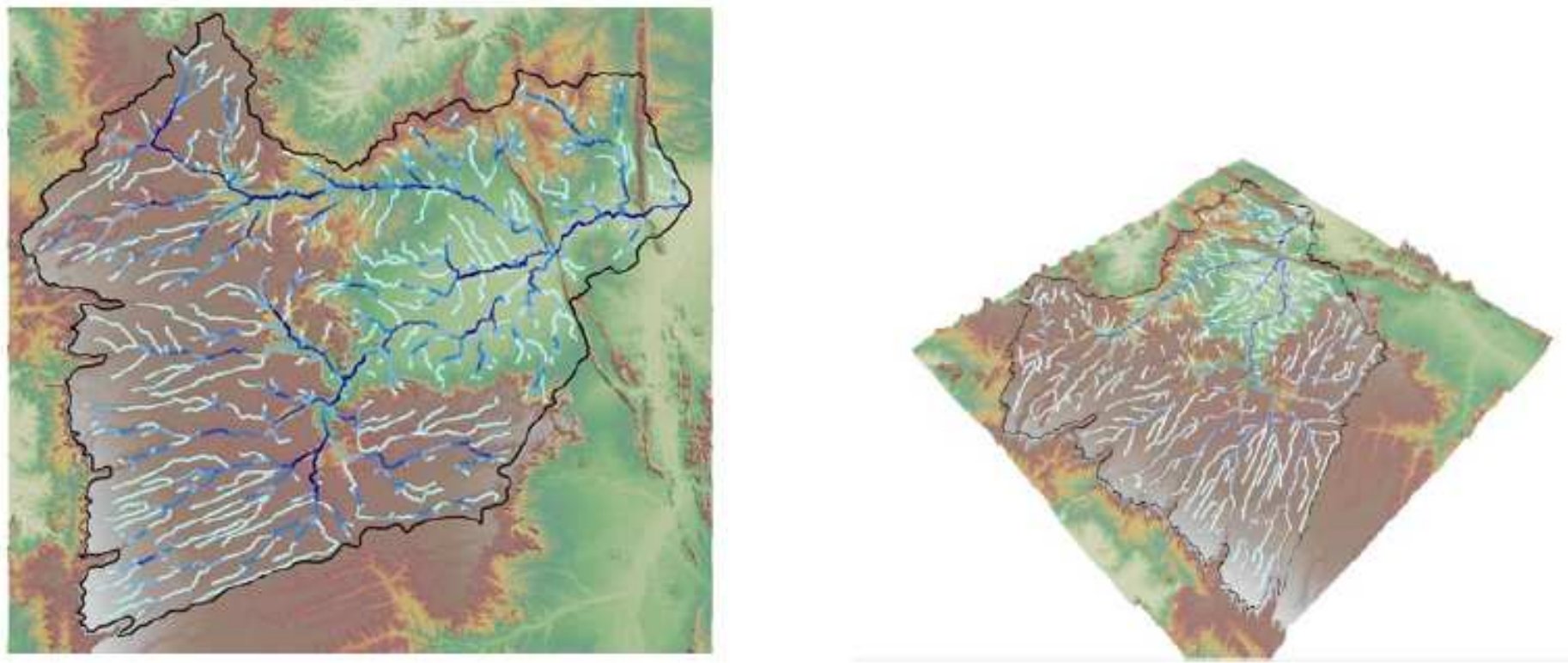

\section{Figure 5}

Flow of the Rio Grande DEM stream. Rio Grande DEM 3D Note: The designations employed and the presentation of the material on this map do not imply the expression of any opinion whatsoever on the part of Research Square concerning the legal status of any country, territory, city or area or of its authorities, or concerning the delimitation of its frontiers or boundaries. This map has been provided by the authors.

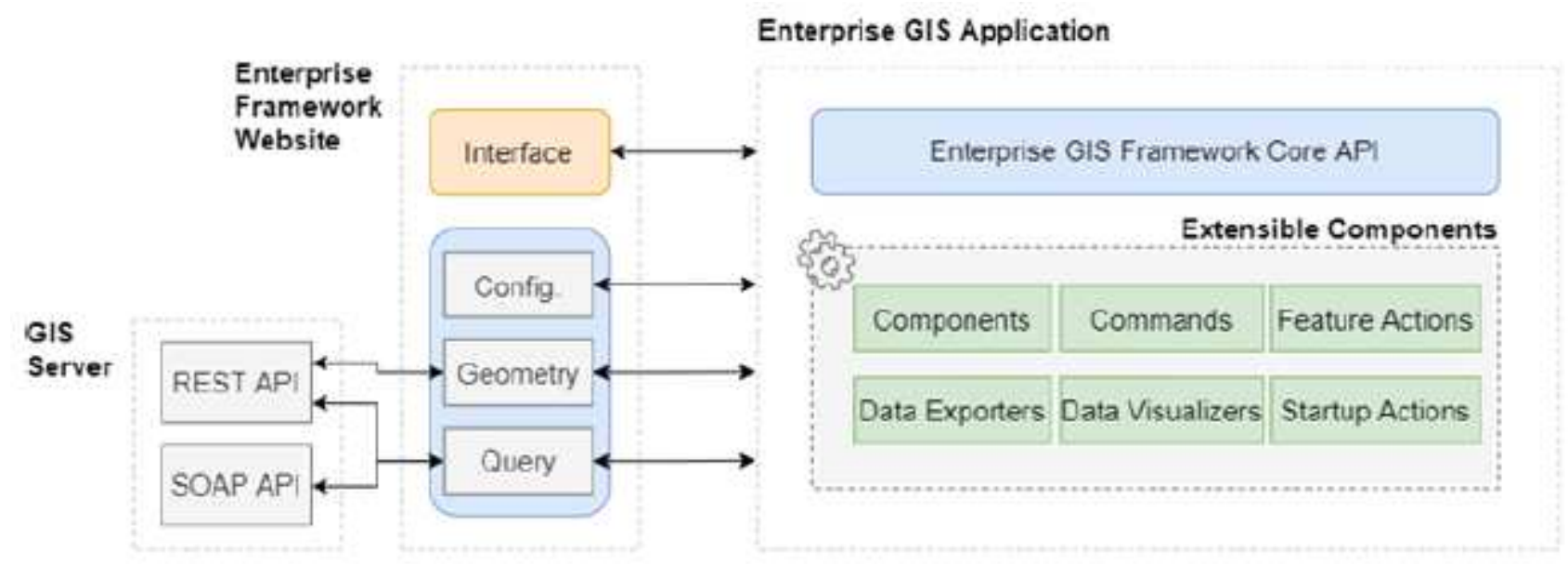

Source An adapted figure from [42]

Figure 6

ArcGIS Framework 
Coupled Mode: Nowcast, Weather and Climate Models

1.Land Surface Model

2.Grid disaggregation

3.Subsurface Flow Routing

4. Overland Flow Routing

5.Baseflow Model

6.Channel \& Reservoir Routing with water management

7. Grid aggregation

Source: An adapted figure from [3]

Figure 7

WRF-Hydro Structure Source: An 


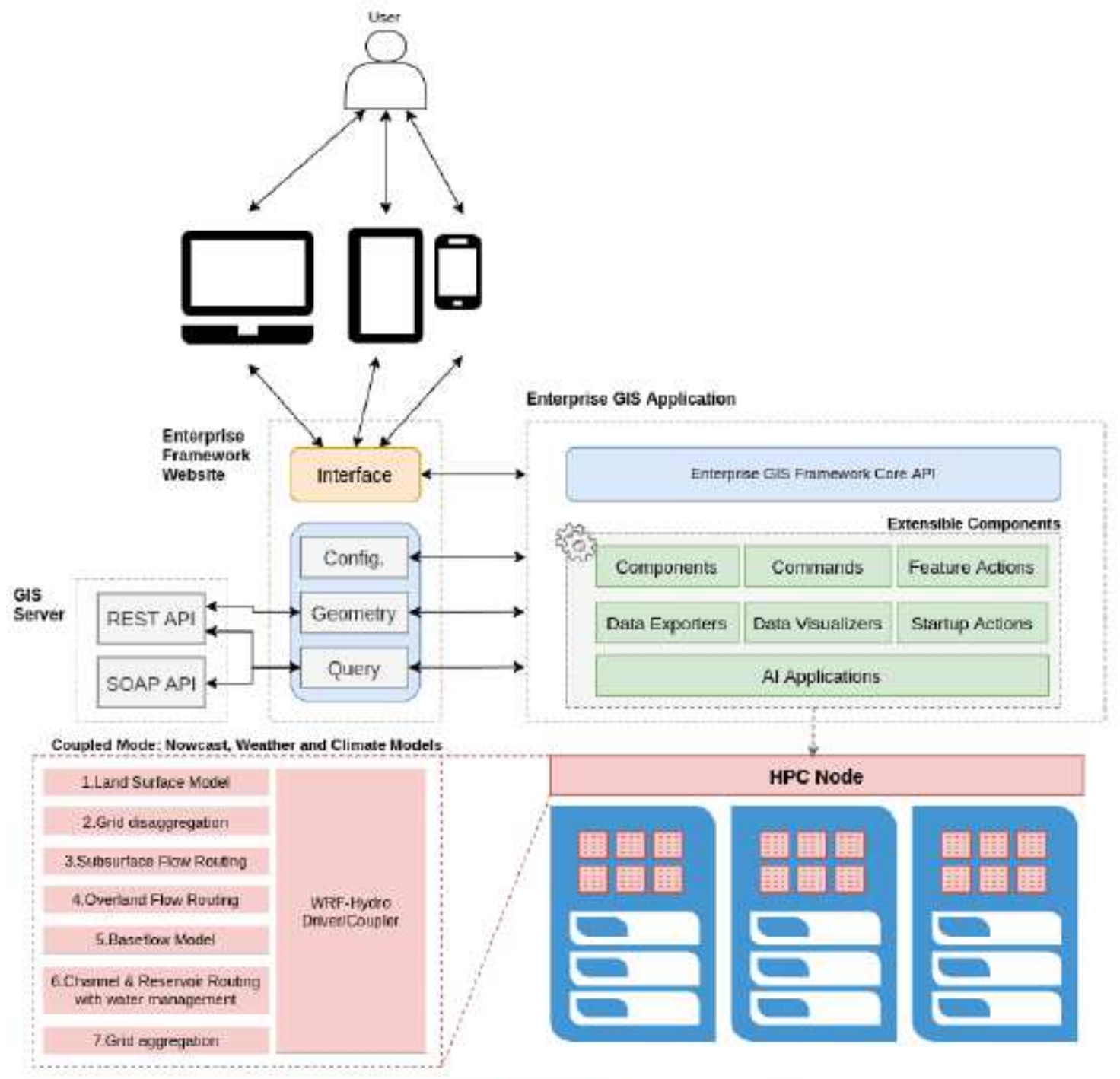

Source: An adapted figure $[3,42]$

Figure 8

WRF-Hydro, ArcGIS, and IA integration structure 